\title{
Studies of Agrometeorological Indices on Hybrids Maize (Zea mays L.) under Different Weather Condition
}

\author{
S. V. Shingne ${ }^{1}$, B. V. Asewar ${ }^{2}$ and G. B. Raut 3* $^{\text {* }}$ \\ ${ }^{1}$ Department of Agriculture Meteorology, ${ }^{2}$ Dry land Agriculture Research Center, \\ ${ }^{3}$ Department of Agriculture Meteorology, VNMKV, Parbhani, Maharashtra, India \\ *Corresponding author
}

\begin{tabular}{l} 
K e y w o r d s \\
Yield, GDD, HTU \\
and PTU \\
Article Info \\
$\begin{array}{l}\text { Accepted: } \\
\text { 04 August } 2020 \\
\text { Available Online: } \\
\text { 10 September } 2020\end{array}$ \\
\hline
\end{tabular}

\section{Keywords}

Yield, GDD, HTU and PTU

\section{Article Info}

Accepted:

Available Online:

10 September 2020

\section{A B S T R A C T}

An investigation was carried out during kharif 2017 at Department of Agricultural Meteorology, College of Agriculture, Vasantrao Naik Marathwada Krishi Vidyapeeth, Parbhani, entitled "Performance of maize hybrids (Zea mays L.) under different sowing windows" The experiment was laid out in a FRBD design where main plots were assigned to five sowing dates and sub-plots to two Cultivars of maize, with ten treatment combinations and replicated thrice. The treatment comprised the five date of sowing i.e. $25^{\text {th }} \mathrm{MW}, 26^{\text {th }} \mathrm{MW}, 27^{\text {th }} \mathrm{MW}, 28^{\text {th }} \mathrm{MW}$ and $29^{\text {th }} \mathrm{MW}$ and two cultivars, $\mathrm{H}_{1}$ (Pioneer 3501), $\mathrm{H}_{2}$ (Monsanto 9126). The results revealed that among the five different dates of sowing. $\mathrm{D}_{1}-25^{\text {th }}$ MW sowing and hybrid $\mathrm{H}_{1}$ (PIONEER-3501) resulted in crop sown with higher growth and yield parameters significantly i.e. Plant height, functional leaves, days to $50 \%$ tasseling, days to $50 \%$ silking, Number of cob per plant, length of cob, diameter of cob, Number of grain per cob and test weight also first date of sowing $D_{1} 25^{\text {th }}$ MW significantly highest grain yield $\left(4969 \mathrm{~kg} / \mathrm{ha}^{-1}\right)$ followed by $\mathrm{D}_{2}\left(4816 \mathrm{~kg} / \mathrm{ha}^{-1}\right), \mathrm{D}_{3}(4627$ $\left.\mathrm{kg} / \mathrm{ha}^{-1}\right) \mathrm{D}_{4}\left(4424 \mathrm{~kg} / \mathrm{ha}^{-1}\right)$ and $\mathrm{D}_{5}\left(4131 \mathrm{~kg} / \mathrm{ha}^{-1}\right)$ and among hybrid $\mathrm{H}_{1}$ (PIONEER-3501) $\left(4609 \mathrm{~kg} / \mathrm{ha}^{-1}\right.$ ) and $\mathrm{H}_{2}$ (MONSANTO-9126) $\left(4578 \mathrm{~kg} / \mathrm{ha}^{-1}\right)$ respectively. The highest total GDD was observed with $\mathrm{D}_{3} 27^{\text {th }} \mathrm{MW}$ sowing date i.e. $2498.7{ }^{\circ} \mathrm{C}$ day and hybrid $\mathrm{H}_{2}$ (Monsanto 9126) i.e. $3008.9{ }^{\circ} \mathrm{C}$ day similarly the highest HTU was observed with $\mathrm{D}_{3} 27^{\text {th }}$ MW sowing date i.e. $13521.2{ }^{\circ} \mathrm{C}$ day/hr and hybrid $\mathrm{H}_{2}$ (Monsanto 9126) i.e. $16723.3{ }^{\circ} \mathrm{C}$ day/hr. PTU observed during total crop growth period was highest in $\mathrm{D}_{4} 28^{\text {th }}$ MW i.e. $37321.2{ }^{\circ} \mathrm{C}$ day/hr as compare to remaining treatments. In case of hybrid PTU was highest in $\mathrm{H}_{2}$ (Monsanto 9126) i.e. $38283.9^{\circ} \mathrm{C}$ day/hr. The highest GDD, HTU and PTU was observed in hybrid $\mathrm{H}_{2}$ (Monsanto 9126) as compare to $\mathrm{H}_{1}$ (Pioneer 3501). In case of date of sowing the highest GDD and HTU in $\mathrm{D}_{3} 27^{\text {th }} \mathrm{MW}$ and PTU was highest in $\mathrm{D}_{4} 28^{\text {th }}$ MW.

\section{Introduction}

Maize is called as queen of cereal due to its great importance in human, animal diet and high yielding ability. It efficiently utilizes solar energy and has immense potential for higher yield and called as "Miracle Crop". Maize plays a vital role in ensuring food security as well as nutritional security through quality protein (Rawool, 2004). Maize is a 
versatile crop grown over a range of agro climatic zones. In fact the suitability of maize to diverse environments is unmatched by any other crop. It is grown from $58 \mathrm{oN}$ to $40 \mathrm{oS}$, from below sea level to altitudes higher than $3000 \mathrm{~m}$, and in areas with $250 \mathrm{~mm}$ to more than $5000 \mathrm{~mm}$ of rainfall per year (Shaw, 1988 and Dowswell et al., 1996) and with a growing cycle ranging from 3 to 13 months (CIMMYT 2000). However, the major maize production areas are located in temperate regions of the globe. The United States, China, Brazil and Mexico account for $70 \%$ of global production. India has $5 \%$ of corn acreage and contributes $2 \%$ of world production. Maize is principally a rainy season crop and requires a minimum soil temperature of $13^{\circ} \mathrm{C}$ for germination and root development (optimum range $21^{\circ} \mathrm{C}-27^{\circ} \mathrm{C}$ ). It response well to warm conditions (optimum of $21^{\circ} \mathrm{C}-30^{\circ} \mathrm{C}$ ) as growth increases with temperature up to $30^{\circ} \mathrm{C}$. In India, area and production of maize are about 9.23 million hectares and 23.73 million tonnes respectively, having average productivity about $2564 \mathrm{~kg}$ ha-1. In Maharashtra, the area and production of maize is about 1.05 million hectares and 2.20 million tonnes production with the productivity of $2080 \mathrm{~kg} \mathrm{ha}^{-1}$, The productivity of maize in Marathwada is low (1983 $\mathrm{kg} \mathrm{ha}^{-1}$ ) as compared to Maharashtra (Anonymous, 2015). It ranked next to rice, wheat and sorghum in respect of area and production. Though it is consumed all over the country but it is a staple food of people in hilly and sub mountain area of North India. It is extensively grown in Uttar Pradesh, Bihar, Rajasthan, Madhya Pradesh etc. (Dayanand and Jain, 1994). Negative effect of some abiotic and biotic stresson plant, sowing date can play a major role in determining the seed yield, quality, seed germination and understanding whole phenological stages in many regions. Some researchers pointed out that especially, the effect of sowing date and plant density on corn expressed that delay in sowing reduces the number of kernels in corn (Cantarero et al., (2000). Shumway et al., (1992) found that delay in sowing reduce quality performance and performance components of maize. Early and intermediate sowings tend to best utilize solar radiation for grain production.

\section{Materials and Methods}

The field experiment was conducted during the Kharif 2017 at Research farm of Department of Agricultural Meteorology, college of Agriculture Parbhani to study the performance of maize hybrids (Zea mays L.) under different sowing windows. The experiment was laid out in Factorial Randomized Block Design replicated three times. The treatments comprised of five dates of sowing i.e., $25^{\text {th }} \mathrm{MW}, 26^{\text {th }} \mathrm{MW}, 27^{\text {th }} \mathrm{MW}$, $28^{\text {th }} \mathrm{MW}$ and $29^{\text {th }} \mathrm{MW}$ in main plots and two maize hybrid $\mathrm{H}_{1}$ (PIONEER-3501) and $\mathrm{H}_{2}$ (MONSANTO-9126) in sub plots. Gross and net plot sizes were $6.0 \times 5.0 \mathrm{~m}^{2}$ and $4.8 \times 4.2$ $\mathrm{m}^{2}$, respectively. Sowing was done by dibbling method with spacing of $60 \times 30 \mathrm{~cm}$. The entire recommended packages of practices were adopted. The crop was harvested at physiological maturity. Data on growth, yields and, micrometeorological parameters were recorded as per procedure. The observations pertaining to all biometric observation 15 days interval and post-harvest yield attributes observations were recorded at harvest. Agro-meteorological indices were computed for different phenophases of crop.

\section{Growing degree days ( ${ }^{0} \mathrm{C}$ day)}

Growing Degree Days is defined as "the sum over the growing season of a crop of the difference between the daily temperature and a reference temperature . GDD was expressed in terms of ${ }^{\circ} \mathrm{C}$ day. The growing degree days (GDD) was worked out by considering the base temperature of $10{ }^{\circ} \mathrm{C}$ (Patel et al., 1999). 
The total growing degree days (GDD) for different phenophases were determined by the following formula-

$$
\mathrm{GDD}\left({ }^{\circ} \mathrm{C} \text { day } / \mathrm{hr}\right)=\sum_{\mathrm{i}=1}^{\mathrm{n}}\left[\left(\mathrm{T}_{\max }+\mathrm{T}_{\min }\right) / 2\right]-\mathrm{T}_{\mathrm{b}}
$$

Where,

GDD = Growing degree days

$\mathrm{T}_{\max }=$ Daily maximum temperature $\left({ }^{0} \mathrm{C}\right)$

$\mathrm{T}_{\text {min }}=$ Daily minimum temperature $\left({ }^{0} \mathrm{C}\right)$

$\mathrm{T}_{\mathrm{b}}=$ Base temperature $\left(10{ }^{0} \mathrm{C}\right)$

\section{Helio-thermal Units (HTU) $\left({ }^{0} \mathrm{C}\right.$ day hrs)}

The HTU may be defined as "the accumulated product of GDD and Bright sun shine hours between the developmental thresholds for each day" and HTU was expressed in terms of ${ }^{\circ} \mathrm{C}$ day hrs.

The HTU is the product of GDD and mean daily hours of bright sun shine. The sum of HTU for each phenophase was worked out by following equation which was given by Nagamani et.al (2015).

\section{HTU $\quad\left({ }^{\circ} \mathrm{C}\right.$ day $\left./ \mathrm{hrs}\right)=\mathrm{GDD} \times \mathrm{BSS}$}

Where,

HTU $=$ Helio Thermal Units GDD = Growing Degree days

BSS $=$ Bright Sun Shine Hours

\section{Photo Thermal Unit (PTU) ( ${ }^{0} \mathrm{C}$ day hrs)}

PTU may be defined as "the product of growing degree days and the day length" expressed in terms of ${ }^{\circ} \mathrm{C}$ day hrs. PTU was computed by using following formula. This was proposed by Gudadhe et al., (2013).

PTU $\quad\left({ }^{\circ} \mathrm{C}\right.$ day hrs $)=$ GDD $x$ Day length
Where,

PTU $=$ Photo Thermal Units

GDD $=$ Growing Degree days

\section{Results and Discussion}

\section{Yields}

The data on mean grain, straw and biological yield of maize as influenced by different sowing dates and hybrids are given in Table 1. the data indicated that mean grain, straw and biological yield was $4593 \mathrm{~kg} \mathrm{ha}^{-1}, 9443$ $\mathrm{kg} \mathrm{ha}{ }^{-1}$ and $14036 \mathrm{~kg} \mathrm{ha}^{-1}$ respectively. Different date of sowing significantly influenced the grains and straw yields. The maize sown in $\mathrm{D}_{1} 25^{\text {th }} \mathrm{MW}$ produced significantly higher grain yield $\left(4969 \mathrm{~kg} / \mathrm{ha}^{-1}\right)$ and followed by $\mathrm{D}_{2}\left(4816 \mathrm{~kg} / \mathrm{ha}^{-1}\right), \mathrm{D}_{3}(4627$ $\left.\mathrm{kg} / \mathrm{ha}^{-1}\right), \mathrm{D}_{4}\left(4424 \mathrm{~kg} / \mathrm{ha}^{-1}\right)$ and $\mathrm{D}_{5}$ (4131 $\left.\mathrm{kg} / \mathrm{ha}^{-1}\right)$. There was $7 \%, 11 \%$ and $17 \%$ reduction in the grain yield in $27^{\text {th }} \mathrm{MW}, 28^{\text {th }}$ MW and $29^{\text {th }}$ MW. This might be due to delayed sowing as compared to first date of sowing i.e. $25^{\text {th }}$ MW. However among hybrid $\mathrm{H}_{1}$ (PIONEER 3501) was (4609 kg/ha-1) and $\mathrm{H}_{2} \quad$ (MONSANTO 9126) (4578 $\mathrm{kg} / \mathrm{ha}^{-1}$ ) respectively. These results were in conformity by Rahman et al., (2001) and Sulochana et al., (2015).

The straw and biological yield was produced significantly higher in $25^{\text {th }} \mathrm{MW}$ as compare to rest of sowing dates and first hybrid $\mathrm{H}_{1}$ (PIONEER 3501) was more yield as compare to $\mathrm{H}_{2}$ (MONSANTO 9126) respectively. Sowing of maize during different sowing dates significantly influenced growth and yield characters. Plant height, functional leaves, days to $50 \%$ tasseling, days to $50 \%$ silking, Number of cob per plant, length of cob, diameter of cob, Number of grain per cob and test weight were significantly more when maize sown during $25^{\text {th }} \mathrm{MW}$ and hybrid $\mathrm{H}_{1}$ (PIONEER 3501) was most favoured of the growth and yield contributing characters. 


\section{Agro-meteorological indices}

\section{Growing degree days (GDD)}

Growing degree days (GDD) for hybrids maize crop under different sowing dates from sowing to maturity are presented in Table 2 . Data Revealed that the mean total heat requirement during crop life cycle i.e. Sowing to seedling/sprouting to Milk to physiological maturity $\left(\mathrm{P}_{1}\right.$ to $\left.\mathrm{P}_{6}\right)$ was $2483.3{ }^{\circ} \mathrm{C}$. The total heat load was reported during $\mathrm{D}_{1} 25^{\text {th }} \mathrm{MW}$ was $2484.0{ }^{\circ} \mathrm{C}$ day and it was followed by $\mathrm{D}_{2}$ $26^{\text {th }}$ MW $\left(2492.7{ }^{0} \mathrm{C}\right), \mathrm{D}_{3} 27^{\text {th }}$ MW (2498.7 $\left.{ }^{0} \mathrm{C}\right), \mathrm{D}_{4} 28^{\text {th }} \mathrm{MW}\left(2478.1{ }^{0} \mathrm{C}\right)$ and $\mathrm{D}_{5} 29^{\text {th }} \mathrm{MW}$ $\left(2463.2{ }^{\circ} \mathrm{C}\right)$ day. It indicated that the total heat load was increased from $D_{1}$ to $D_{3}$ and again decreased at $\mathrm{D}_{4} 28^{\text {th }} \mathrm{MW}$ it may be due to delayed sowing occurred during crop life cycle. Whereas, Date of sowing $\mathrm{D}_{3} 27^{\text {th }} \mathrm{MW}$ indicated more heat load (i.e. $2498.7{ }^{0} \mathrm{C}$ day) than rest of the treatments it may be due to maximum air temperature prevailed at sowing time. Date of sowing $\mathrm{D}_{5} 29^{\text {th }} \mathrm{MW}$ lowest heat load (i.e. $2463.2{ }^{0} \mathrm{C}$ day). Heat unit required for attaining various phenophases in $\mathrm{D}_{4} 27^{\text {th }}$ MW date of sowing due to effect of temperature and delayed sowing during the crop growing season. It will definitely affect GDD of hybrids maize crop. The data presented in Table 2 revealed that the mean heat requirement of hybrid during crop life cycle from $2967.8{ }^{0} \mathrm{C}$. The total heat load reported in hybrids during crop life cycle was $\mathrm{H}_{1}$ (Pioneer 3501) 2926.7 ${ }^{0} \mathrm{C}$ and $\mathrm{H}_{2}$ (Monsanto 9126) $3008.9{ }^{0} \mathrm{C}$. It may be occurred due to different crop duration, from emergence to maturity of such Cultivars Similar results were reported by Majumder et al (2016).

Table.1 Yield of hybrids maize under different treatments

\begin{tabular}{|c|c|c|c|c|}
\hline \multirow[t]{2}{*}{ Treatments } & \multicolumn{4}{|c|}{ Post-harvest Observation } \\
\hline & $\begin{array}{c}\text { Grain yield (kg } \\
\left.\text { ha }^{-1}\right)\end{array}$ & $\begin{array}{c}\text { Stover yield (kg } \\
\left.\text { ha }^{-1}\right)\end{array}$ & $\begin{array}{l}\text { Biological Yield } \\
\quad\left(\mathrm{kg} \mathrm{ha}^{-1}\right)\end{array}$ & $\begin{array}{l}\text { Harvest Index } \\
(\%)\end{array}$ \\
\hline \multicolumn{5}{|c|}{ Date of Sowing } \\
\hline$D_{1}\left(25^{\text {th }}\right.$ SMW $)$ & 4969 & 10825 & 15794 & 31.46 \\
\hline$D_{2}\left(26^{\text {th }}\right.$ SMW $)$ & 4816 & 10302 & 15118 & 31.85 \\
\hline $\mathrm{D}_{3}\left(27^{\text {th }} \mathrm{SMW}\right)$ & 4627 & 9658 & 14285 & 32.39 \\
\hline$D_{4}\left(28^{\text {th }}\right.$ SMW $)$ & 4424 & 9597 & 13885 & 31.86 \\
\hline$D_{5}\left(29^{\text {th }} S M W\right)$ & 4131 & 9337 & 14021 & 29.46 \\
\hline S.E. \pm & 57.39 & 51.17 & 108.56 & 0.52 \\
\hline CD at $5 \%$ & 170.27 & 151.81 & 322.08 & NS \\
\hline \multicolumn{5}{|c|}{ Hybrids } \\
\hline $\begin{array}{c}\mathrm{H}_{1} \text { (PIONEER } \\
\text { 3501) }\end{array}$ & 4609 & 10047 & 14656 & 31.44 \\
\hline $\begin{array}{c}\mathrm{H}_{2} \text { (MONSANTO } \\
9126)\end{array}$ & 4578 & 9840 & 14418 & 31.75 \\
\hline S.E \pm & 36.30 & 32.36 & 68.66 & 0.52 \\
\hline CD at $5 \%$ & 107.69 & 96.00 & 203.69 & NS \\
\hline \multicolumn{5}{|c|}{ Interaction $(\mathrm{D} \times \mathrm{V})$} \\
\hline S.E \pm & 81.16 & 92.36 & 173.52 & 0.46 \\
\hline CD at $5 \%$ & NS & NS & NS & NS \\
\hline General Mean & 4593 & 9443 & 14036 & 32.72 \\
\hline
\end{tabular}


Table.2 Accumulated Growing Degree Day (GDD ${ }^{\circ} \mathrm{C}$ day) to attain various phenophases in maize under different date of sowing

\begin{tabular}{|c|c|c|c|c|c|c|c|c|}
\hline \multirow[t]{2}{*}{ Treatment } & \multicolumn{8}{|c|}{ Phenophases of maize } \\
\hline & $\mathbf{P}_{1}$ & $\mathbf{P}_{2}$ & $\mathbf{P}_{3}$ & $\mathbf{P}_{4}$ & $\mathbf{P}_{5}$ & $\mathbf{P}_{6}$ & Total & Mean \\
\hline \multicolumn{9}{|l|}{ Dates of sowing } \\
\hline$D_{1}(\mathrm{SMW} 25)$ & 230.2 & 978.6 & 296.0 & 124.0 & 271.3 & 583.9 & 2484.0 & 414.0 \\
\hline $\mathrm{D}_{2}(\mathrm{SMW} 26)$ & 215.2 & 976.6 & 281.1 & 118.5 & 312.8 & 588.5 & 2492.7 & 415.4 \\
\hline$D_{3}$ (SMW 27) & 219.3 & 995.4 & 271.5 & 121.7 & 293.7 & 596.6 & 2498.7 & 416.3 \\
\hline $\mathrm{D}_{4}(\mathrm{SMW} 28)$ & 230.6 & 957.2 & 285.2 & 127.2 & 284.8 & 593.1 & 2478.1 & 413.0 \\
\hline$D_{5}$ (SMW 29) & 256.0 & 979.8 & 268.8 & 103.3 & 245.7 & 609.7 & 2463.2 & 410.5 \\
\hline Mean & 230.3 & 977.5 & 280.5 & 118.9 & 281.7 & 594.4 & 2483.3 & 413.8 \\
\hline \multicolumn{9}{|l|}{ Hybrids } \\
\hline H$_{1}($ PIONEER 3501) & 312.5 & 840.0 & 352.3 & 197.4 & 413.3 & 811.2 & 2926.7 & 487.8 \\
\hline $\mathrm{H}_{2}($ MONSANTO 9126) & 257.5 & 867.5 & 407.4 & 324.8 & 424.6 & 727.1 & 3008.9 & 501.5 \\
\hline Mean & 285.0 & 853.8 & 379.9 & 261.1 & 419.0 & 769.2 & 2967.8 & 494.7 \\
\hline
\end{tabular}

$\mathrm{P}_{1}$ : Sowing to seedling/sprouting. $\mathrm{P}_{2}$ : Seedling /sprouting to grand growth. $\mathrm{P}_{3}$ : Grand growth to tasseling. $\mathrm{P}_{4}$ : Tasseling to silking. $\mathrm{P}_{5}$ : Silking to milk. $\mathrm{P}_{6}$ : Milk to physiological maturity

Table.3 Accumulated Helio Thermal Unit (HTU ${ }^{\circ} \mathrm{C}$ day hrs) to attain various phenophases in maize under different date of sowing

\begin{tabular}{|c|c|c|c|c|c|c|c|c|}
\hline \multirow[t]{2}{*}{ Treatment } & \multicolumn{8}{|c|}{ Phenophases of maize } \\
\hline & $\mathbf{P}_{1}$ & $\mathbf{P}_{2}$ & $\mathbf{P}_{3}$ & $\mathbf{P}_{4}$ & $\mathbf{P}_{5}$ & $\mathbf{P}_{6}$ & Total & Mean \\
\hline \multicolumn{9}{|l|}{ Dates of sowing } \\
\hline D $($ SMW 25) & 2140.8 & 4305.8 & 1480.0 & 607.6 & 949.5 & 3561.8 & 13045.6 & 2174.3 \\
\hline $\mathrm{D}_{2}(\mathrm{SMW} 26)$ & 774.7 & 4587.7 & 1208.7 & 379.2 & 2001.9 & 3589.8 & 12542.1 & 2090.3 \\
\hline D $($ SMW 27) & 1622.5 & 4081.1 & 977.4 & 547.6 & 2204.2 & 3818.2 & 13521.2 & 2208.5 \\
\hline $\mathrm{D}_{4}$ (SMW 28) & 530.6 & 4211.7 & 1311.9 & 1144.8 & 1509.4 & 4092.4 & 12800.8 & 2133.7 \\
\hline D5 (SMW 29) & 716.8 & 4507.1 & 2016.0 & 630.1 & 1253.1 & 4206.9 & 13330.1 & 2221.7 \\
\hline Mean & 1157.1 & 4338.7 & 1398.8 & 661.9 & 1583.6 & 3853.8 & 13048.0 & 2165.7 \\
\hline \multicolumn{9}{|l|}{ Hybrids } \\
\hline $\mathrm{H}_{1}$ (PIONEER 3501) & 2500.0 & 3444.0 & 1937.6 & 1085.7 & 1735.9 & 5435.1 & 13138.2 & 2689.7 \\
\hline $\mathrm{H}_{2}$ (MONSANTO 9126) & 2394.7 & 3470.0 & 2403.7 & 1071.9 & 2802.4 & 4580.7 & 16723.3 & 2787.2 \\
\hline Mean & 2447.4 & 3457.0 & 2170.7 & 1078.8 & 2269.2 & 5007.9 & 14930.8 & 2738.5 \\
\hline
\end{tabular}


Table.4 Accumulated Photo Thermal Unit (PTU ${ }^{\circ} \mathrm{C}$ day hrs) to attain various phenophases in maize under different date of sowing

\begin{tabular}{|c|c|c|c|c|c|c|c|c|}
\hline \multirow[t]{2}{*}{ Treatment } & \multicolumn{8}{|c|}{ Phenophases of maize } \\
\hline & $\mathbf{P}_{1}$ & $\mathbf{P}_{2}$ & $\mathbf{P}_{3}$ & $\mathbf{P}_{4}$ & $\mathbf{P}_{5}$ & $\mathbf{P}_{6}$ & Total & Mean \\
\hline \multicolumn{9}{|c|}{ Dates of sowing } \\
\hline $\mathrm{D}_{1}$ (SMW 25) & 2688.3 & 12956.6 & 3904.2 & 1556.2 & 3388.5 & 7211.7 & 31705.1 & 5284.2 \\
\hline $\mathrm{D}_{2}$ (SMW 26) & 2847.1 & 12969.2 & 3541.9 & 1480.1 & 3878.7 & 7209.1 & 31926.1 & 5321.0 \\
\hline D $_{3}$ (SMW 27) & 2894.8 & 13099.9 & 3391.1 & 1511.5 & 3915.0 & 7272.6 & 32084.8 & 5347.5 \\
\hline $\mathrm{D}_{4}(\mathrm{SMW} 28)$ & 3039.3 & 12472.2 & 9542.2 & 1569.6 & 3491.6 & 7206.2 & 37321.2 & 6220.2 \\
\hline D $_{5}$ (SMW 29) & 3363.8 & 12649.2 & 3319.7 & 1268.5 & 3009.8 & 7377.4 & 30988.4 & 5164.7 \\
\hline Mean & 2966.7 & 12829.4 & 4739.8 & 1477.2 & 3536.7 & 7255.4 & 32805.1 & 5467.5 \\
\hline \multicolumn{9}{|c|}{ Hybrids } \\
\hline $\mathrm{H}_{1}$ (PIONEER 3501) & 4134.4 & 11079.1 & 4692.6 & 2475.4 & 5137.3 & 9880.4 & 37399.2 & 6233.2 \\
\hline $\mathrm{H}_{2}$ (MONSANTO 9126) & 3406.7 & 11451.0 & 5320.6 & 4053.5 & 5239.6 & 8812.4 & 38283.9 & 6380.6 \\
\hline Mean & 3770.6 & 11265.1 & 5006.6 & 3264.5 & 5188.5 & 9346.4 & 37841.6 & 6306.9 \\
\hline
\end{tabular}

\section{Helio-thermal units (HTU)}

The Helio-thermal units (HTU) for hybrids maize crop under different sowing dates from sowing to maturity are presented in Table 3. revealed that the mean total helio-thermal units (HTU) observed during crop life cycle i.e. Sowing to seedling/sprouting to Milk to physiological maturity $\left(\mathrm{P}_{1}\right.$ to $\left.\mathrm{P}_{6}\right)$ in date of sowing $\left(\mathrm{D}_{1}\right.$ to $\left.\mathrm{D}_{5}\right) 13048.0{ }^{0} \mathrm{C}$ day hrs. The helio-thermal units were higher in first date of sowing $\mathrm{D}_{3} 27^{\text {th }} \mathrm{MW}$ i.e. $13521.20 \mathrm{C}$ day hrs.

The lowest HTU were observed in $\mathrm{D}_{2} 26^{\text {th }}$ MW i.e. $12542.1{ }^{0} \mathrm{C}$ day hrs than rest of the treatments due to variation of temperature and bright sunshine hours during the crop growing season. The data depicted in Table 3 revealed that the total mean helio-thermal unit (HTU) requirement for Two hybrids during crop life cycle was $14930.8{ }^{0} \mathrm{C}$ day hrs. The heliothermal units (HTU) were higher in $\mathrm{H}_{2}$ (Monsanto 9126) i.e. $16723.3{ }^{0} \mathrm{C}$ day hrs and the lowest HTU were observed in $\mathrm{H}_{1}$ (Pioneer 3501) $13138.2{ }^{0} \mathrm{C}$ day hrs. It may be due to different growth period. Similar results were reported by Singh et al., (2013).

\section{Photo-thermal Units (PTU)}

The data presented in Table 4 revealed that mean total Photo-thermal Units (PTU) required in the life cycle i.e. Sowing to seedling/sprouting to Milk to physiological maturity $\left(\mathrm{P}_{1}\right.$ to $\left.\mathrm{P}_{6}\right)$ stage was $32805.1{ }^{0} \mathrm{C}$ day hrs for sowing date. Date of sowing $\mathrm{D}_{4} 28^{\text {th }}$ MW required more PTU i.e. $37321.2{ }^{\circ} \mathrm{C}$ day hrs than rest of the treatments, it may be due to maximum air temperature prevailed at sowing time. Date of sowing $\mathrm{D}_{5} 29^{\text {th }} \mathrm{MW}$ required lowest heat load i.e. $30988.4{ }^{0} \mathrm{C}$ day hrs heat unit for attaining various phenophases due to effect of temperature during the crop growing season. The data depicted in Table 3 revealed that the total mean Photo thermal unit (PTU) requirement for Two hybrids during crop life cycle was $37841.6{ }^{0} \mathrm{C}$ day hrs. The Photo thermal units (PTU) were higher in $\mathrm{H}_{2}$ (Monsanto 9126) i.e. $38283.9{ }^{\circ} \mathrm{C}$ day hrs and the lowest PTU were observed in $\mathrm{H}_{1}$ (Pioneer 3501) $37399.2{ }^{0} \mathrm{C}$ day hrs. It might be due to the different crop duration in above Varieties. Similar results were reported by Thavaprakaash et al., (2007). 
In conclusion based on the above findings, it may be concluded that Sowing dates in June $\mathrm{D}_{1} 25^{\text {th }} \mathrm{MW}$ and maize hybrid $\mathrm{H}_{1}$ (PIONEER 3501) superior and better as compare to other treatments is appropriate in terms higher physiological maturity and yield. Build up of GDD, HTU and PTU are good estimators to study maize phenology and can be used as a reliable tool to optimize the sowing period for different maize cultivars. It is also useful for the appraisal of yield potential of maize in different dates of sowing.

\section{References}

Anonymous, 2015. The current status published on website http://www.indiastat.in.

Cantarero, M. G., Lugue, S. F. and Rubiolo, O. J. 2000. Effects of sowing date and plant density on grain number and yield of a maize hybrid in the central region of Cordoba, Argentina. J. Agric. Sci., 17:3-10.

CIMMYT. 2000. CGIAR Research, Areas of Research: Maize (Zea mays L.).

<http://www.cgiar.org/areas/maize.htm>.

Dayanand and Jain, O. P. 1994. Rabi maize cultivation for enhanced production.India Fm., 43 (10): 11-12.

Dowswell, C. R., Paliwal, R. L. and Cantrell, R. P. 1996. In maize in the third world. Winrock development orientated literature studies. Boulder, colorado: westview press. pp. 212-215.

Gudadhe, N.N., Neeraj Kumar, Pisal, R.R., Mote, B.M. and Dhonde, M.B.2013. Evaluation of agrometeorological indices in relation to crop phenology of cotton (Gossippium spp.) and chickpea (Cicer aritinum L.) at Rahuri region of Maharashtra. Trends in Biosciences, 6(3): 246-250.

Majumder, D., Kingra, P.K. and Kukal S.S., 2016. Canopy temperature and heat use efficiency of spring maize under modified soil microenvironment. Ann.
Agric. Res. Vol. 37 (3): 225-235.

Nagamani, C., Sumanthi, V. And Reddy, G.P. 2015. Performance of rabi pigeonpea under varied times of sowing nutrient dose and foliar sprays. Prog. Agric. 15(2): 253-258.

Patel, H.R., Shekh, A.M., Bapujirao, B., Chaudhari, G.B. and Khushu, M.K.1999. AN assessment of phenology, thermal time and phasic development model of pigeonpea (Zea mays L.). Journal of Agrometeorology 1(2): 149-154.

Rahman, M. A., Magboul, E. L. and Abdelatief, E. N. 2001. Effects of sowing date and cultivar on the yield and yield components of maize in northern Sudan, paper presented at the Seventh Eastern and Southern Africa Regional Maize Conference.

Rawool, H. V. 2004. Effect of integrated nutrient management on yield and

nutrient balance in maize (Zea mays L.). Indian J. Agril. Sci., 46(4): 698-701.

Shaw, R. H. 1988. Climate Requirement. In: Sprague, C.F. and Dudley, J.W. (eds.) Corn and Corn Improvement. ASA, Madison, WI.

Shumway, C. R., Cothren, J. T., SernaSaldivar, S. O. and Rooney, L. W. 1992. Planting date and moisture level effects on grain yield, physical grain quality, and alkaline-processing characteristics of food grade maize. Crop Sci., 32:1265-1269.

Sulochana, Solanki, N. S., Dhewa, J. S. and Bajia, R. 2015. Effect of sowing dates on growth, phenology and agro meterological indices for maize varieties. An International Quarterly Journal of Life Sciences. 10(3): 13391343.

Singh, N. K., and amod kumar, 2013. Thermal requirment of maize influenced by planting dates and intrarow spacing. Ijltemas, vol. 2(1): 18-23 
Thavaprakaash, N., Jagannathan, R., Velayudham, K. and Gurusamy, L., 2007. Seasonal Influence on
Phenology and Accumulated Heat Units in Relation to yield of Baby corn. IJAR, Vol 2 (9): 826-831

\section{How to cite this article:}

Shingne, S. V., B. V. Asewar and Raut, G. B. 2020. Studies of Agrometeorological Indices on Hybrids Maize (Zea mays L.) under Different Weather Condition. Int.J.Curr.Microbiol.App.Sci. 9(09): 310-317. doi: https://doi.org/10.20546/ijcmas.2020.909.039 